\title{
New data on the age and geographic distribution of Neoproterozoic plutons near Saint John, New Brunswick
}

\author{
K.L. Currie and V.J. McNicoll \\ Geological Survey of Canada, 601 Booth Street, Ottawa ON K1A OE8
}

Date Received: May 30, 1999

Date Accepted: June 30, 1999

\begin{abstract}
New U-Pb zircon and titanite ages for four plutons from the Brookville and Mascarene blocks of the Saint John region suggest that the age distribution of Neoproterozoic intrusions in the Mascarene block resembles that in the Caledonia block, with older plutons emplaced at $\sim 630-620 \mathrm{Ma}$ (Brittain Creek, $625 \pm 2 \mathrm{Ma}, \mathrm{U}-\mathrm{Pb}$ zircon and titanite; Lingley, $629.3 \pm 0.9 \mathrm{Ma}$, U-Pb zircon), and younger plutons emplaced at about $550 \mathrm{Ma}$. Older plutons are more fractured and altered than younger ones, but not everywhere more strongly foliated. Within the Brookville block, the Hanson Stream pluton gives an age of $532+1 /-3 \mathrm{Ma}(\mathrm{U}-\mathrm{Pb}$ zircon), demonstrating that ${ }^{40} \mathrm{Ar} /{ }^{39} \mathrm{Ar}$ ages as young as ca. $518 \mathrm{Ma}$ from this pluton (Dallmeyer and Nance 1992) indicate postemplacement disturbance. The A-type Harvey Hill pluton, previously thought to be the youngest pluton in the Brookville block, gave a U-Pb zircon age of $544 \pm 4 \mathrm{Ma}$, similar to that of the geochemically similar Bonnell Brook pluton of the Caledonia block. Combined with presence of a distinctive Cambro-Ordovician siliciclastic cover (Saint John Group), these dates indicate that the Mascarene and Caledonia blocks originated in the same continental fragment. Western parts of the Brookville and Mascarene blocks were affected by a Cambrian thermal event (520-510 Ma), which may also be represented in the Caledonia block. Tectonic models based on these data suggest that the Saint John region underwent repeated subduction in Neoproterozoic time and diverse transcurrent movements from Silurian to Carboniferous time.
\end{abstract}

Les nouvelles datations au U-Pb obtenues à partir de zircon et de sphène dans le cas de quatre plutons provenant des massifs de Brookville et de Mascarene dans la région de Saint-Jean permettent de supposer que la répartition des âges des intrusions néoprotérozoïques du massif de Mascarene ressemble à celle du massif de Caledonia : la mise en place des plutons les plus âgés remonte à environ 630 à 620 M.A. (crique Brittain, $625 \pm 2$ M.A., U-Pb à partir de zircon et de sphène; Lingley, 629,3 $\pm 0,9$ M.A., U-Pb à partir de zircon) et celle des plus jeunes, à environ 550 M.A. Les plutons les plus âgés sont plus fracturés et altérés que les plus récents, mais ils sont toujours plus fortement feuilletés. À l'intérieur du massif de Brookville, le pluton du ruisseau Hanson affiche un âge de $532+1 /-3$ M.A. (U-Pb à partir de zircon), ce qui démontre que les datations à partir de ${ }^{40} \mathrm{Ar} /{ }^{39} \mathrm{Ar}$ de seulement 518 M.A. obtenues de ce pluton (Dallmeyer et Nance 1992) témoignent d'une perturbation ultérieure à la mise en place. Le pluton de type A de la colline Harvey, auparavant considéré comme le pluton le plus jeune du massif de Brookville, a inscrit un âge de $544 \pm 4 \mathrm{M}$.A. par datation U-Pb à partir de zircon, ce qui est analogue à l'âge du pluton à structure géochimique semblable du ruisseau Bonnell du massif Caledonia. Ces âges, combinés à la présence d'une couverture silicoclastique du Cambro-Ordovicien (groupe de Saint-Jean), révèlent que les massifs de Mascarene et de Caledonia proviennent du même fragment continental. Les parties occidentales des massifs de Brookville et de Mascarene ont été affectées par un phénomène thermal Cambrien (520-510 M.A.), qui pourrait aussi être représenté dans le massif de Caledonia. Des modèles tectoniques basés sur ces données laissent supposer que la région de Saint-Jean a été soumise à une subduction répétée à l'époque du Protérozoïque supérieur et à des mouvements de décrochement divers du Silurien au Carbonifêre.

[Traduit par la rédaction]

\section{INTRODUCTION}

The Avalon Zone of the Canadian Appalachians forms a collage of diverse, fault-bounded fragments (Williams 1995; Nance and Thompson 1996). Many of the fault slices exhibit little metamorphism and possess a Cambro-Ordovician siliciclastic cover sequence with a distinctive stratigraphy and fauna (Landing 1996) which unconformably or disconformably overlies Neoproterozoic igneous rocks. Others exhibit strong metamorphism and lack the cover sequence (Barr and White 1996), while still others contain early to middle Cambrian bimodal volcanic rocks and minor plutons (Keppie and Murphy 1988; Johnson and McLeod 1996). All of the fragments exhibit two or more periods of Neoproterozoic magmatism, commonly with emplacement ages in the ranges $630-600 \mathrm{Ma}$ and $570-545$ Ma. A maze of faults of uncertain timing and displacement juxtapose slivers of distinct but apparently related rock assemblages. These complex relations have led to divergent interpretations of the Avalon Zone, ranging from mid-Paleozoic assembly of fragments with essentially unrelated Neoproterozoic and lower Paleozoic histories (Barr and White 1996) to dissection of a single continental margin over an extended period. (van Staal et al. 1996).

All three types of fragments have been defined by recent mapping in the Saint John region (Currie 1997; Barr and White 1999; McLeod et al. 1994). Isotopic and geochemical data on plutons within these fragments can be found in Whalen et al., (1994) and Eby and Currie (1996). Previous geochronological data were reviewed by Barr and White (1996). Despite the wealth of data, correlation among the fault-bounded fragments remains controversial. We report here new geochronological data that bear on this question.

\section{GeOLOGICAL SETTING}

The Saint John region comprises five northeast-trending, 
fault-bounded segments (Fig. 1) which have been termed terranes (Barr and White 1996), but are here designated by the non-committal term 'block', because some of them may be fragments of a common protolith. Three of the four faults separating these blocks (Caledonia, Kennebecasis and Belleisle faults) are steep features with long and complex movement histories, including normal movement in Triassic time, low to high-angle reverse motion in late Carboniferous time, and strikeslip motion in early Carboniferous and older time, with deformation becoming more brittle from southwest to northeast (Helmstaedt 1968; Wardle 1978; Rast and Dixon 1982; Leger and Williams 1986; Currie 1987; Park et al. 1994). As a result of complex movement histories, these faults occupy $\mathrm{km}$-scale zones containing numerous movement surfaces of diverse orientation and sense, as well as abundant tectonic inclusions. The fourth fault, the Taylor Brook Fault, is cryptic within the area of Fig. 1, sealed by Siluro-Devonian plutons, but the fault affects the composition of the plutons (McLeod 1990). Farther to the northeast, this fault forms a major lithologic separator, north of which occur slivers of Ordovician mafic volcanic rocks of oceanic affinity (Annidale Group, McLeod et al. 1992).

Southeast of the Caledonia Fault, the Caledonia block contains $\sim 630-600 \mathrm{Ma}$ arc-type plutons which exhibit juvenile isotopic signatures (Whalen et al. 1994), and a coeval volcanosedimentary sequence (Broad River Group, Barr and White 1996). These rocks, as well as a younger bimodal volcanic rocks (Coldbrook Group) and correlative plutons ( $560-550 \mathrm{Ma}$, Barr et al. 1994), are overlain by transgressive, marine, lower Cambrian to lower Ordovician clastic sedimentary rocks (Saint John Group) which bear a distinctive fauna (Landing 1996). Minor amounts of Ordovician and Devonian felsic volcanic rocks occur locally (Barr et al. 1994), and fluviatile siltstone and conglomerate of the southwesterly-derived Carboniferous Mispec Group (Currie and Nance 1983) unconformably overlie other units along the Bay of Fundy.

Between the Caledonia Fault and the Kennebecasis Fault, plutonic and metamorphic rocks predominate in the Brookville block. The Green Head Group (Wardle 1978), a metasedimentary sequence of Precambrian age, comprises marble, quartzite and minor pelite with olistostromes near the top. The rocks are generally at greenschist facies but reach sillimanite grade along the tectonic contact with the Brookville Gneiss, a narrow rib of tonalitic orthogneiss and high temperature-low pressure paragneiss (White 1995). Detrital zircons from the paragneiss component of the Brookville Gneiss gave a maximum age of ca. $640 \mathrm{Ma}$ (Bevier et al. 1990). U- $\mathrm{Pb}$ zircon ages show that the orthogneiss component of the Brookville Gneiss was emplaced at ca. $605 \mathrm{Ma}$ and metamorphosed at ca. $564 \mathrm{Ma}$ (Bevier et al. 1990). Much of the Brookville block is formed by plutonic suites of three distinct types. One suite has $A_{2}$-type chemistry (Eby and Currie 1996), commonly forming high-level aplitic to granophyric bodies. The Musquash pluton of this suite gave a U-Pb zircon age of $550 \pm$ $15 \mathrm{Ma}$ (Currie and Hunt 1991). Another suite ranges from diorite to granite, commonly forming composite bodies which exhibit evidence of mingling of mafic and felsic components (Eby and Currie 1996). This suite was derived from sources similar to those of plutons southeast of the Caledonia fault, with an additional component of old crust (Whalen et al. 1994; Eby and Currie 1996). White (1995) obtained a lower U-Pb zircon age of
$548 \pm 2 \mathrm{Ma}$ from the Fairville pluton, and upper intercept $\mathrm{U}-\mathrm{Pb}$ zircon and titanite ages of $546 \pm 2$ from the Ludgate Lake pluton. A third suite comprises more homogeneous quartz diorite and granodiorite and gives distinctly younger ages. White (1995) reported concordant $\mathrm{U}-\mathrm{Pb}$ zircon and titanite ages of $538 \pm 1 \mathrm{Ma}$ for the Rockwood Park pluton and $537 \pm 2$ Ma for the French Village pluton, and found ${ }^{40} \mathrm{Ar} /{ }^{39} \mathrm{Ar}$ ages as young as $511 \mathrm{Ma}$ for similar plutons (Renforth and Rockwood Park plutons). In the western part of the Brookville block, Dallmeyer and Nance (1992) reported ${ }^{40} \mathrm{Ar} /{ }^{39} \mathrm{Ar}$ ages as young as $518 \mathrm{Ma}$ from the Hanson Stream pluton. Volcanic rocks approximately coeval with the older plutons (ca. $555 \mathrm{Ma}$, Zain Eldeen et al. 1991) occur in fault blocks west of Musquash Harbour. Numerous northeast-trending fault slivers of Saint John Group occur in the Brookville block east of Musquash Harbour. The Carboniferous Mispec Group and Kennebecasis Formation, and Triassic Lepreau Formation, all mainly non-marine red-beds, overlie the plutonic suites unconformably.

Bounded by the Kennebecasis and Belleisle faults, the Kingston block consists of sheeted bimodal dykes and correlative volcanic rocks and plutons of the Silurian Kingston Complex (438-435 Ma, Doig et al. 1990; Eby and Currie 1993; McLeod et al. 1994; Barr et al. 1997). Rare screens of metasedimentary rocks were possibly derived from the Green Head Group (Currie 1987). Dike trends are rotated counter-clockwise from the trend of the bounding faults, implying emplacement during sinistral transtension (Currie 1987; Doig et al. 1990). The central part of the complex is in greenschist facies but grade declines towards the margins (Nance and Dallmeyer 1993).

Between the Belleisle and Taylor Brook faults, the Mascarene block (Fyffe and Fricker 1987) consists of a southern belt of Neoproterozoic and Cambrian rocks (New River belt of McLeod et al. 1994; Barr et al. 1997), intruded on its northern side by voluminous, lobate Siluro-Devonian plutons which form an elongate array along the trace of the Taylor Brook Fault. In the northeastern part of the Mascarene block, the Cambrian to lower Ordovician siliciclastic Saint John Group overlies the Neoproterozoic rocks. In the southwestern part, the Saint John Group is absent, but lower Cambrian bimodal volcanic rocks of the Buckman Creek formation (Helmstaedt 1968; Johnson et al. 1993; Currie 1997) rest unconformably on Neoproterozoic plutons. Prior to this study, no ages greater than ca. $555 \mathrm{Ma}$ (Currie and Hunt 1991; McLeod et al. 1994) were known from the Mascarene block. The Siluro-Devonian volcanosedimentary Mascarene Group unconformably overlies Neoproterozoic and Cambrian rocks. Felsic volcanic rocks in the upper part of the Mascarene Group probably correlate with the voluminous Siluro-Devonian plutons to the north (Payette and Martin 1987).

The Taylor Brook Fault marks the northern boundary of the Avalon Zone (van Staal et al. 1996), although isolated fragments of possible Avalonian affinity occur further to the northwest. In the Saint John region, Precambrian rocks are not found north of the Taylor Brook Fault, where the strata consist of Ordovician-Silurian bathyal grey to green lithic wacke, slate and siltstone (Digdeguash, Sand Brook and Flume Ridge formations, Fyffe and Miller 1992), overlain by Late Devonian deposits of the Mount Pleasant caldera (Piskahegan Group, McCutcheon 1990) and intruded by coeval, highly evolved rapakivi granite and porphyry (Mount Douglas pluton, McLeod 1990). 


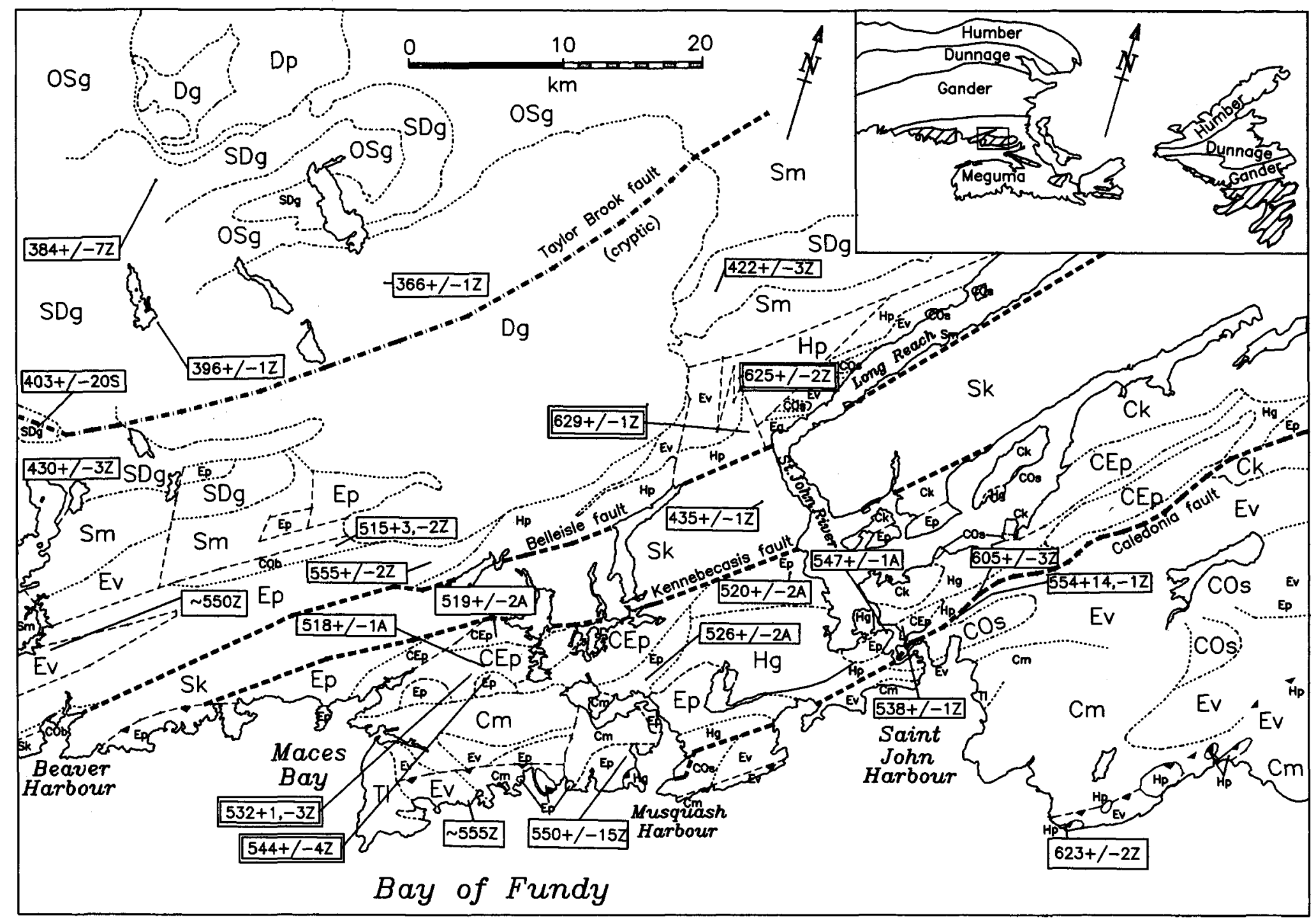

Fig. 1. Simplified geological map of the Saint John region, southern New Brunswick (modified after Currie 1997). The legend (from youngest to oldest) is as follows; Tl, Triassic Lepreau Formation (conglomerate); Ck, Carboniferous Kennebecasis Formation (conglomerate); Cm, Carboniferous Mispec Group (red conglomerate/black siltstone); Dp, Devonian Piskahegan Group (volcanogenic sediments and flows); Dg, Devonian granite and porphyry (Mount Douglas pluton and related rocks); SDg, Siluro-Devonian granite, peralkaline granite, minor gabbro (Welsford, Jake Lee, Utopia, Bocabec and Magaguadavic plutons); Sm, Mascarene Group (siltstone and bimodal volcanic rocks, comagmatic with SDg in part); Sk, Kingston Complex (bimodal sheeted dikes and related pluton and volcanic rocks); OSg, Ordovician and Silurian bathyal wacke and siltstone (Digdeguash, Sand Brook and Flume Ridge formations); COb, Cambrian Buckman Creek Formation (bimodal volcanics, siltstone); COs, Cambro-Ordovician Saint John Group (siltstone, thin ash beds); CEp, Cambrian or Neoproterozoic plutons (540-530 Ma); Ep, Neoproterozoic plutons (555-545 Ma); Ev, Neoproterozoic Coldbrook Group and correlative rocks ( $550 \mathrm{Ma}$, bimodal volcanics); Hp, Neoproterozoic deformed arc-type plutons (625-600 Ma); Hg, Neoproterozoic or older Green Head Group (marble, quartzite, pelite). In the Bay of Fundy thrust belt, teeth are shown on the thrust block. Other faults (dashed lines) exhibit complex motions. Age data are identified by $\mathrm{Z}$ for U-Pb zircon determinations, $\mathrm{A}$ for ${ }^{40} \mathrm{Ar} /{ }^{39} \mathrm{Ar}$ ages, and $\mathrm{S}$ for ages determined by the $\mathrm{Rb}$-Sr method. Sources of data are given in the bibliography. New data are double boxed. The inset map shows the zonal structure of the Canadian Appalachians (Williams 1995), and the location of Avalonian terranes (hachured). The heavy box shows the location of the detailed map. 


\section{GEOCHRONOLOGY}

On the basis of the preceding observations, we have attempted to answer three specific questions. (i) Does the Mascarene block contain igneous rocks with ages $>600$ Ma like the other two blocks which contain Neoproterozoic rocks? (ii) Was an A-type granite suite emplaced at ca. $550 \mathrm{Ma}$ in all three terranes, as proposed by Eby and Currie (1996)? (iii) Did igneous activity continue in the Brookville block until <520 Ma?

\section{U-Pb Analytical Methods}

Heavy mineral concentrations were prepared by standard crushing, grinding, Wilfley table, and heavy liquid techniques. Mineral separates were sorted by magnetic susceptibility using a Frantz isodynamic separator. $\mathrm{U}-\mathrm{Pb}$ analytical methods utilized in this study are those outlined in Parrish et al. (1987) and Davis et al. (1997). Treatment of analytical errors follows Roddick (1987). Analytical results are presented in Table 1, where errors on the ages are reported at the $2 \sigma$ level, and displayed in concordia plots (Figs. $2-5$ ). The analyzed multigrain zircon fractions were very strongly air abraded following the method of Krogh (1982). U-Pb sample locations are shown in Fig. 1.

\section{Brittain Creek pluton}

Currie (1997) mapped a triangular mass of homogeneous coarse-grained, altered tonalite and granodiorite as the Brittain Creek pluton (Fig. 1), which he considered, on the basis of field observations, to be the oldest pluton of the Mascarene block. The mass is bounded on the north by a major fault against Silurian volcanic rocks. To the south, minor faulting disrupts an unconformity against the overlying Saint John Group, and the Neoproterozoic volcaniclastic rocks that disconformably underlie the Saint John Group. To the west, the pluton is truncated against the Lingley pluton along a set of northnorthwest and northeast-trending normal faults. The rock has been fractured and brecciated with an intensity that increases toward the southwest. Microscopically, the pluton consists of a subhedral aggregate of altered hornblende and plagioclase with minor chloritised biotite and interstitial quartz. Hornblende has been almost entirely altered to epidote and chlorite. Relics of igneous zoning can be seen in strongly saussuritised plagioclase but the only fresh twinned plagioclase is almost pure albite, obviously of secondary origin. Breccia veins exhibit growth of a second generation of chlorite in vug-like cavities. Zircon and titanite occur as stubby brownish subhedral grains associated with chloritised biotite. Chemical data are not available for the Brittain Creek pluton. The pluton was sampled in road cuts along Highway 177 about $5 \mathrm{~km}$ north of Lingley (sample site UTM 19, $713050 \mathrm{E}, 5028920 \mathrm{~N}$ ).

Five zircon fractions of various morphologies were analyzed from this sample. Fractions $\mathrm{A} 1$ and $\mathrm{A} 2$ are comprised of elongate, euhedral crystals with minor inclusions; fraction B contains clear, stubby, well-faceted prisms. A weighted average of the ${ }^{206} \mathrm{~Pb} /{ }^{238} \mathrm{U}$ ages of fractions $\mathrm{A} 1, \mathrm{~A} 2$, and $\mathrm{B}$ has a value of $625 \pm 2 \mathrm{Ma}$, which is taken to be the best estimate for the crystallization age of the rock (Fig. 2; Table 1). Zircon fraction C contains small, stubby prismatic crystals with numerous fluid inclusions and is interpreted to contain an inherited component. Fraction D, comprised of larger (about 100 microns in size)
Brittoin Creek Pluton: CP-96-24

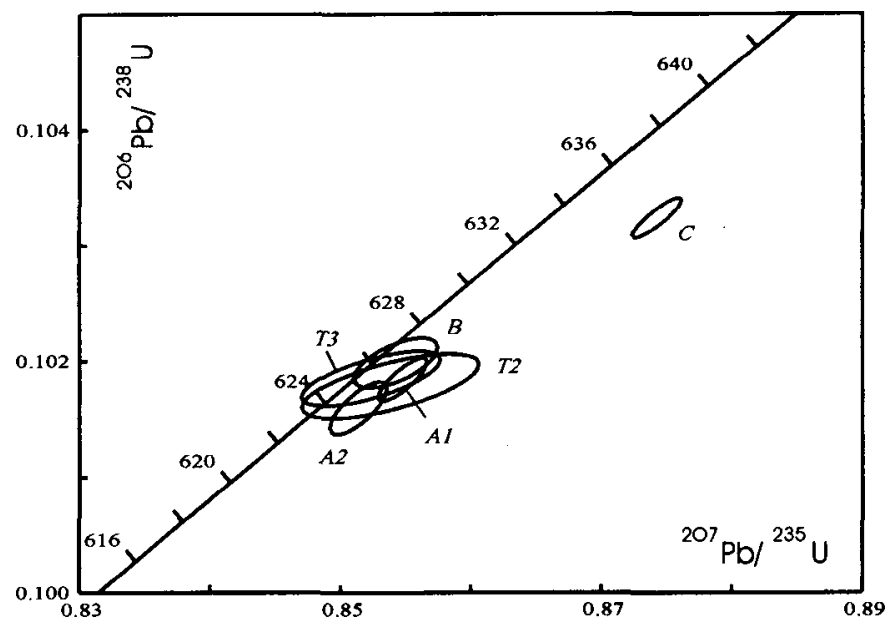

Fig. 2. U-Pb concordia diagram of zircon and titanite analyses, Brittain Creek Pluton (CP-96-Z4).

euhedral, stubby prismatic grains with fluid inclusions, also contains an inherited component and is not plotted on the concordia diagram (see Table 1). Two fractions of subfaceted fragments of light brown (T2) and dark brown (T3) titanite were also analyzed from this sample. A weighted average of the ${ }^{206} \mathrm{~Pb} /{ }^{238} \mathrm{U}$ ages of these two analyses is $625 \pm 1 \mathrm{Ma}$, which is in agreement with the interpreted crystallization age of the rock.

\section{Lingley pluton}

The Lingley pluton forms one of several elongate masses of quartz-feldspar porphyry extending discontinuously for more than $30 \mathrm{~km}$ along the northwest side of the Belleisle Fault (Fig. 1). All are associated with felsic volcanic and minor sedimentary rocks, and petrographically closely resemble one another, but complex faulting in this region makes it difficult to state unequivocally that they are all correlative, or parts of a once continuous body. The porphyry exhibits a distinctive ivory to greenish-ivory shade, in some cases with pink flecks. In thin section the rock contains about 15 percent of corroded quartz phenocrysts, commonly cracked or reduced to fragments, and a few strongly altered plagioclase phenocrysts in a fine-grained matrix of quartz and strongly sericitised feldspar, with small fragments of cognate fine-grained felsic rocks, and rare, small inclusions of a mature quartz sandstone of unknown origin. Like the Brittain Creek pluton, the Lingley pluton was shattered by later deformation, but in this case the shattering appears to have been imposed on a rock which already contained a large number of fragments. Eby and Currie (1996) showed that the Lingley pluton is of $A_{2}$-type, and chemically resembles the Fairville pluton of the Brookville block (U-Pb zircon age $548 \pm 2 \mathrm{Ma}$ ), and the Bonnell Brook pluton of the Caledonia block (U-Pb zircon age $550 \pm 1 \mathrm{Ma}$ ). On this basis, they suggested that the Lingley pluton might have an age of $\sim 550 \mathrm{Ma}$. The Lingley pluton was sampled in large new road cuts along Highway 7 about $2 \mathrm{~km}$ northwest of Lingley (sample site UTM 19, $714900 \mathrm{E}, 5026650 \mathrm{~N}$ ).

Five zircon fractions were analyzed, representing various zircon populations in the sample. Zircon fractions B1 and B2 contain water clear, well faceted, stubby prisms. A weighted average of the ${ }^{206} \mathrm{~Pb} /{ }^{238} \mathrm{U}$ ages of concordant fraction $\mathrm{B} 1$ and 
Table 1. U-Pb analytical data

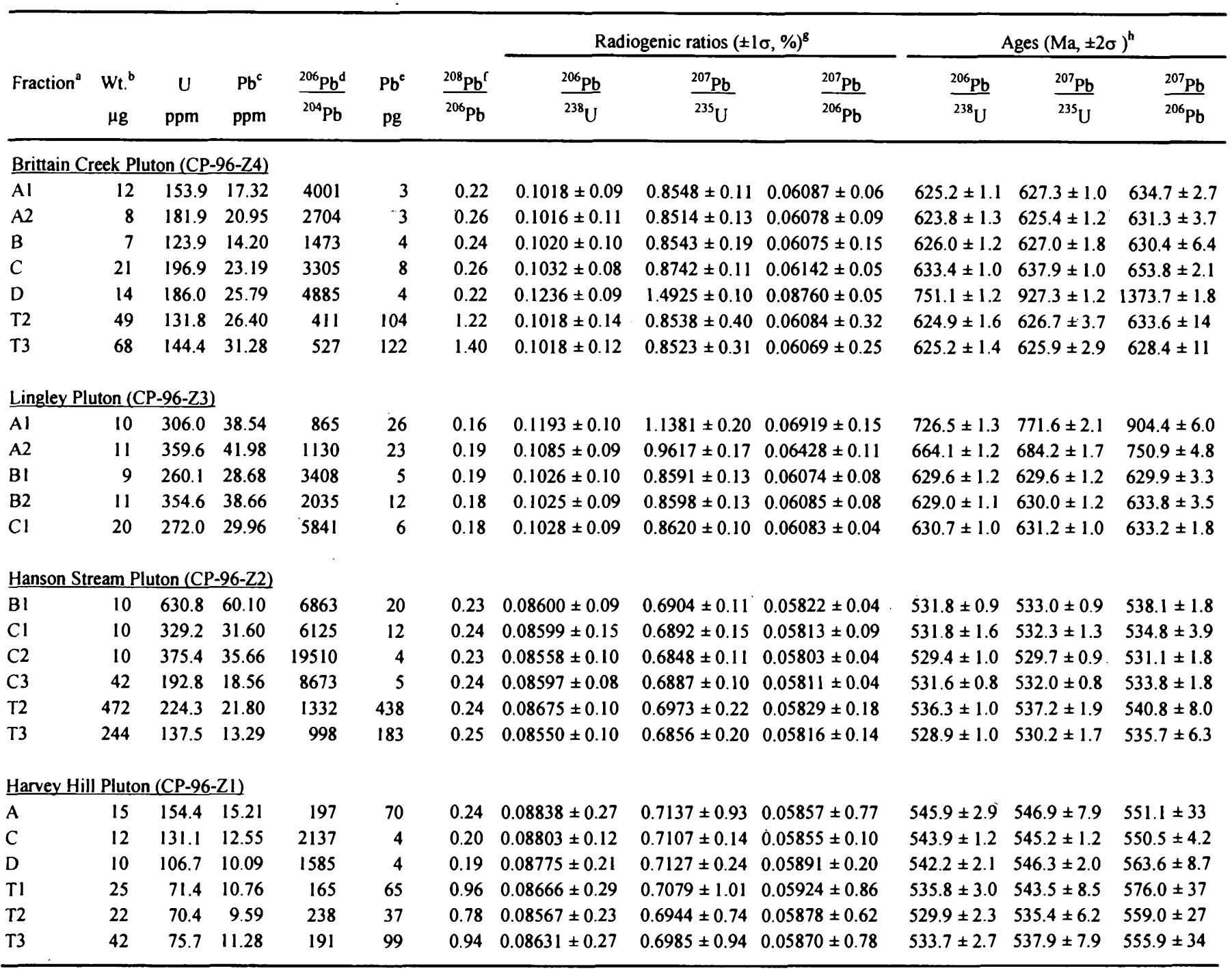

\footnotetext{
${ }^{a}$ All zircon fractions were strongly abraded; $T=$ titanite.

${ }^{b}$ Error on weight is $\pm 1 \mu \mathrm{g}$.

${ }^{\mathrm{c}}$ Radiogenic $\mathrm{Pb}$.

${ }^{\mathrm{d}}$ Measured ratio corrected for spike and $\mathrm{Pb}$ fractionation of $0.09 \pm 0.03 \% / \mathrm{AMU}$.

e Total common $\mathrm{Pb}$ on analysis corrected for fractionation and spike.

'Radiogenic $\mathrm{Pb}$.

${ }^{8}$ Corrected for blank $\mathrm{Pb}$ and $\mathrm{U}$ and common $\mathrm{Pb}$ (Stacey-Kramers model $\mathrm{Pb}$ composition equivalent to the ${ }^{207} \mathrm{~Pb} /{ }^{206} \mathrm{~Pb}$ age).

${ }^{\text {h }}$ Corrected for blank and common $\mathrm{Pb}$.
}

overlapping fraction B2 is $629.3 \pm 0.9 \mathrm{Ma}$ (Fig. 3, Table 1). This date is taken to represent the crystallization age of the rock. Fraction $\mathrm{Cl}$, composed of elongate euhedral crystals with minor inclusions, is interpreted to contain a minor inherited component. Fractions A1 and A2 are well faceted, stubby prisms selected from a slightly more magnetic zircon population and are interpreted to contain inherited components of possible Middle Proterozoic age.

\section{Hanson Stream pluton}

The Hanson Stream pluton forms a large ovoid mass elongated along tectonic strike in the western part of the Brookville block (Fig. 1). The pluton consists of grey, medium to coarse-grained unfoliated hornblende-biotite granodiorite to monzogranite. Rounded, partly assimilated, mafic inclusions up to $30 \mathrm{~cm}$ in diameter are abundant and characteristic. Eby and Currie (1996) reported chemical data for the Hanson Stream pluton. To the east, the pluton intruded tonalite to granodiorite of the Shadow Lake pluton with formation of igneous breccias along the contact. On the basis of map pattern, Currie (1987) deduced that the Harvey Hill pluton intruded the Hanson Stream pluton, but no exposure or definitive evidence of this relation has been found. The Hanson Stream pluton was sampled in large, fresh road cuts along access roads to Highway 1 (sample site UTM 19, 702660E, 5006240N). The sample consists of hypidiomorphic, moderately altered tablets of plagioclase and hornblende, with interstitial mosaic quartz and subordinate green 
Lingley Pluton: CP-96-23

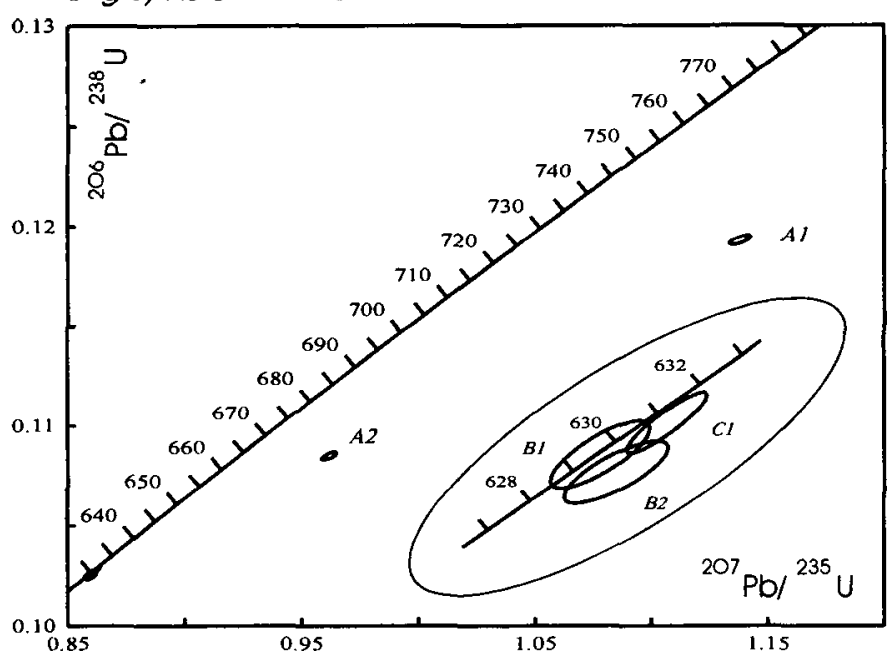

Fig. 3. U-Pb concordia diagram of zircon analyses, Lingley Pluton (CP96-Z3).

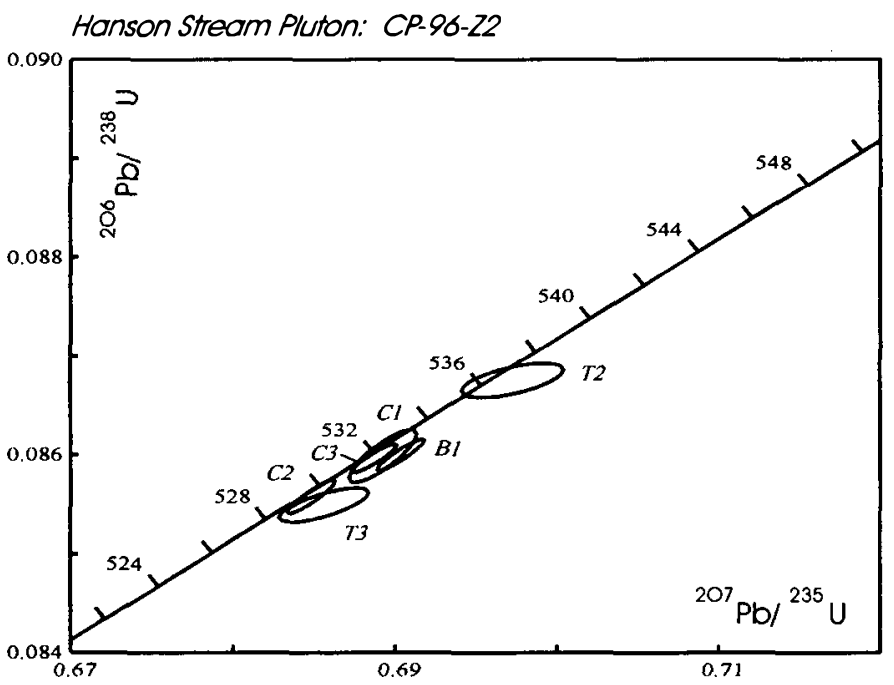

Fig. 4. U-Pb concordia diagram of zircon and titanite analyses, Hanson Stream Pluton (CP-96-Z2).

Harvey Hill Pluton: CP-96-ZI

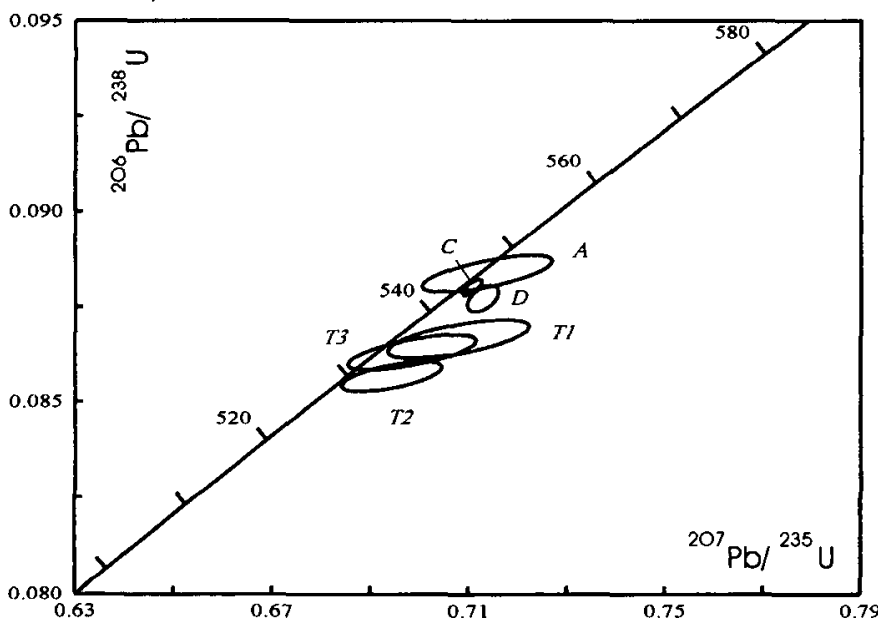

Fig. 5. U-Pb concordia diagram of zircon and titanite analyses, Harvey Hill Pluton (CP-96-Z1). biotite. Potash feldspar (orthoclase) occurs as large ovoid grains overprinting the other minerals. Zircon occurs as stubby, rounded prisms associated with both biotite and hornblende. Titanite occurs as small subhedral grains in homblende.

Zircon fractions analyzed from this sample include large (>105 microns), euhedral prisms (B1), euhedral, stubby grains (C1 and $\mathrm{C} 3$ ) and slightly elongate prismatic crystals (C2). Most of the zircons analyzed contain minor fluidal inclusions. Three of the zircon analyses overlap and intersect concordia; a weighted average of the ${ }^{206} \mathrm{~Pb} /{ }^{238} \mathrm{U}$ ages of fractions $\mathrm{Cl}, \mathrm{C3}$, and $\mathrm{B} 1$ is $531.7 \pm 0.7 \mathrm{Ma}$ (Fig. 4, Table 1). The fourth zircon fraction (C2) intersects concordia and has $\mathrm{a}^{206} \mathrm{~Pb} /{ }^{238} \mathrm{U}$ age of $529.4 \pm 1.0 \mathrm{Ma}$; this fraction may have undergone a minor amount of $\mathrm{Pb}$ loss. The best interpretation for the crystallization age of the rock is taken to be $532+1 /-3$ Ma. Two fractions of clear, anhedral, golden brown (T3) and light brown (T2) titanite fragments were analyzed from the sample. One of the analyses possibly contains an inherited component (T2). The age of the second titanite analysis is in agreement with the age of zircon fraction C2 and may also have undergone minor $\mathrm{Pb}$ loss.

\section{Harvey Hill pluton}

The Harvey Hill pluton forms a subcircular mass of fine to medium-grained, locally porphyritic, red granite and granophyre. No contacts have been found, but the pluton has sharp contacts on radiometric surveys (Shives 1986), and on the basis of this data has been thought to intrude all surrounding preCarboniferous rocks. The Harvey Hill pluton exhibits an unusual $A_{2}$-type chemistry, as discussed by Eby and Currie (1996). The pluton was sampled in rock cuts along access roads to Highway 1 (sample site UTM 19, E, N). The sample consists of an allotriomorphic aggregate of quartz, microcline and albite with some larger, embayed feldspar grains. Brown to olive green biotite, commonly chloritised, occurs sparingly in single grains or aggregates. Allotriomorphic aggregates of pale buff titanite, commonly associated with magnetite, are almost as abundant as biotite. Zircon occurs as minute stubby prisms in biotite.

This sample contains small, well-faceted, stubby prismatic zircons with fluidal inclusions. Three fractions have overlapping analyses; a weighted average of the ${ }^{206} \mathrm{~Pb} /{ }^{238} \mathrm{U}$ ages of fractions $A, C$, and $D$ is $544 \pm 4 \mathrm{Ma}$ (Fig. 5, Table 1). This date is taken to be the crystallization age of the rock. Three fractions of clear, anhedral, light brown titanite fragments were also analyzed from this sample. These analyses give distinctly younger ages, although the weighted average of the three titanite ages, $533 \pm 7$ Ma (Fig. 5, Table 1), has a $2 \sigma$ error which just overlaps the $2 \sigma$ error of the weighted average zircon age. The overlap is so slight that the titanite ages probably reflect a post-emplacement thermal event.

\section{DISCUSSION}

Our data clearly show that older rocks, coeval with the Broad River Group, and correlative plutons in the Caledonia block occur in relative abundance in the Mascarene block. Currie (1997) concluded on the basis of field observation that the Brittain Creek pluton is the oldest pluton within this block; the age determination of $625 \pm 2 \mathrm{Ma}$ agrees with these observations. The age of $629.3 \pm 0.9 \mathrm{Ma}$ for the Lingley pluton contradicts the 
opinions of both McLeod et al. (1994), who considered this pluton to be of Neoproterozoic to Cambrian age, and Eby and Currie (1996), who correlated it with ca. 550 Ma plutons on geochemical grounds. Saint John Group and related strata appear to unconformably overlie the Lingley pluton, but no other clear field evidence of age relationships has been found. Eby and Currie (1992) noted that basalt apparently associated with porphyries of Lingley type is more primitive than basalt of the $\sim 550 \mathrm{Ma}$ Coldbrook Group of the Caledonia block, more closely resembling basalt of the $\sim 625$ Ma Broad River Group. The age of the Lingley pluton suggests that similar subvolcanic porphyries and felsic volcanic rocks along the north shore of the Long Reach may have similar ages, rather than the Cambrian ages assumed by McLeod et al. (1994). A zircon age of ca. 555 $\mathrm{Ma}$ has recently been reported for felsic volcanic rocks on the south shore of the Long Reach (Barr et al. 1997), but there appear to be no obvious field criteria for assigning ages to such rocks, a situation similar to that in the Caledonia block (Barr $e t$ al. 1994).

The age of $532+1 /-3 \mathrm{Ma}$ for the Hanson Stream pluton, combined with earlier data from the Brookville block, make it clear that the ${ }^{40} \mathrm{Ar}{ }^{39} \mathrm{Ar}$ ages of less than $520 \mathrm{Ma}$ in this block do not represent emplacement ages, but post-emplacement thermal events. The ca. $532 \mathrm{Ma}$ age for this pluton confirms that the 540$530 \mathrm{Ma}$ igneous event discovered by Bevier et al. (1990) extends the length of the Brookville block. This event significantly postdated emplacement of $A_{2}$-type plutons such as Harvey Hill. Reexamination of thin sections of the latter exhibit a distinct mosaic recrystallisation, now attributed to the effect of intrusion of the Hanson Stream pluton, an event probably also reflected by the relatively young titanite ages (ca. $533 \mathrm{Ma}$ ) from the Harvey Hill Pluton. Intrusion of the $A_{2}$-type plutons in the Brookville block appears to have been confined to the period $555-545 \mathrm{Ma}$, preceding an igneous event of different character by $\sim 10 \mathrm{Ma}$.

\section{Implications for block correlation}

Neoproterozoic rocks in the Saint John region occur in the Caledonia, Brookville and Mascarene blocks. Attempts to correlate these fragments have elicited two hypotheses, namely (i) that the three fragments all derive from the same source, are not separated by large lateral displacements, and hence display a common igneous history, or (ii) that the three fragments derive from differing sources, have been juxtaposed by large lateral displacements of post-middle Cambrian age, and hence display diverse Neoproterozoic igneous histories.

In light of previous and present data, derivation of the Mascarene and Caledonia blocks from the same source appears probable. The age distribution of Neoproterozoic igneous rocks is essentially identical in both blocks with emplacement of plutons and volcanics at 630-605 Ma and 570-545 Ma. The stratigraphically distinctive Saint John Group unconformably overlies Neoproterozoic rocks in both slices. In our opinion these facts establish that the two blocks originally came from the same continental fragment, and were attached to that fragment until at least lower Ordovician time (youngest strata of the Saint John Group). This does not imply that the two blocks were originally contiguous. They are separated by three major faults, and may have lain tens or hundreds of $\mathrm{km}$ apart. Large-scale relative motions between the Caledonia and Mascarene blocks subsequent to lower Ordovician time could be responsible for presence of abundant Siluro-Devonian sedimentary and igneous rocks in the Mascarene block compared to their scarcity in the Caledonia block.

The Brookville block differs from the Caledonia and Mascarene blocks in several respects. The oldest strata within the block, the Green Head Group, are a shelf-type sedimentary sequence which has no correlatives in the Caledonia or Mascarene blocks. The Brookville block exhibits two periods of Neoproterozoic magmatism, but the older period (>600 Ma), while overlapping in age with flanking blocks, appears to be slightly younger. High temperature-low pressure metamorphism at ca. $565 \mathrm{Ma}$ (White 1995), typical of the Brookville block, does not appear in flanking blocks. Younger igneous ages fall into two groups, one ca. 555-545 Ma and the other ca. 540-530 Ma. The former age is well represented in the Caledonia and Mascarene blocks, but the latter has no known correlatives within these blocks. Mid-to late Cambrian thermal disturbance in the Brookville block, indicated by numerous ${ }^{40} \mathrm{Ar} /{ }^{39} \mathrm{Ar}$ ages $<520$ Ma (Dallmeyer and Nance 1992; White 1995), is coeval with stratigraphic and radiometric ages (early to middle Cambrian, ca. $510 \mathrm{Ma}$ ) of basaltic volcanic rocks in the Mascarene block (Helmstaedt 1968: Johnson et al. 1993). Lamprophyric intrusions in the Saint John Group of the Caledonia block may be of similar age.

Despite obvious differences, several lines of evidence indicate that the Brookville block was connected to the Caledonia/Mascarene block by ca. $550 \mathrm{Ma}$. Igneous rocks of 555-545 Ma age and similar chemical character are found in all three blocks (Whalen et al. 1994). Although the Saint John Group and related Neoproterozoic strata are not found in place within the Brookville block, the ubiquitous occurrence of fault slivers (more than a dozen occurrences) implies a stratigraphic or tectonic cover of Saint John Group over much of the Brookville block at some time in the past.

The detailed tectonic history of the Saint John region cannot be unravelled at present. A possible scenario might include the following elements, diagrammed in Fig. 6.

(a) At about $630-605 \mathrm{Ma}$, subduction brought a continent or continental fragment with the Green Head Group as a passive margin sequence against a continental margin including the Caledonia and Mascarene blocks, producing extensive arc magmatism in the latter (Broad River Group and correlative plutons including Brittain Creek and Lingley).

(b) At about 565-545 Ma an intense thermal event involving upwelling of mantle material occurred beneath the former collision zone, possibly as a result of crustal delamination after collision (Whalen et al. 1994). This event produced bimodal and $\mathrm{A}_{2}$-type magmatism (Coldbrook Group and correlative plutons, including Harvey Hill) and accompanying high temperature-low pressure metamorphism.

(c) From 540-530 Ma, large-scale magmatism occurred in the Brookville block only, implying that the Brookville block separated from the Mascarene-Caledonia block during or shortly after the ca. $550 \mathrm{Ma}$ event. In the model of Whalen et al. (1994) this separation was ascribed to rifting and spreading over a mantle upwelling. The subsequent 540-530 Ma magmatism in the Brookville block appears subduction-related (White and Barr 1996), which could be explained by subduction beneath the Brookville block producing a second collision between the 

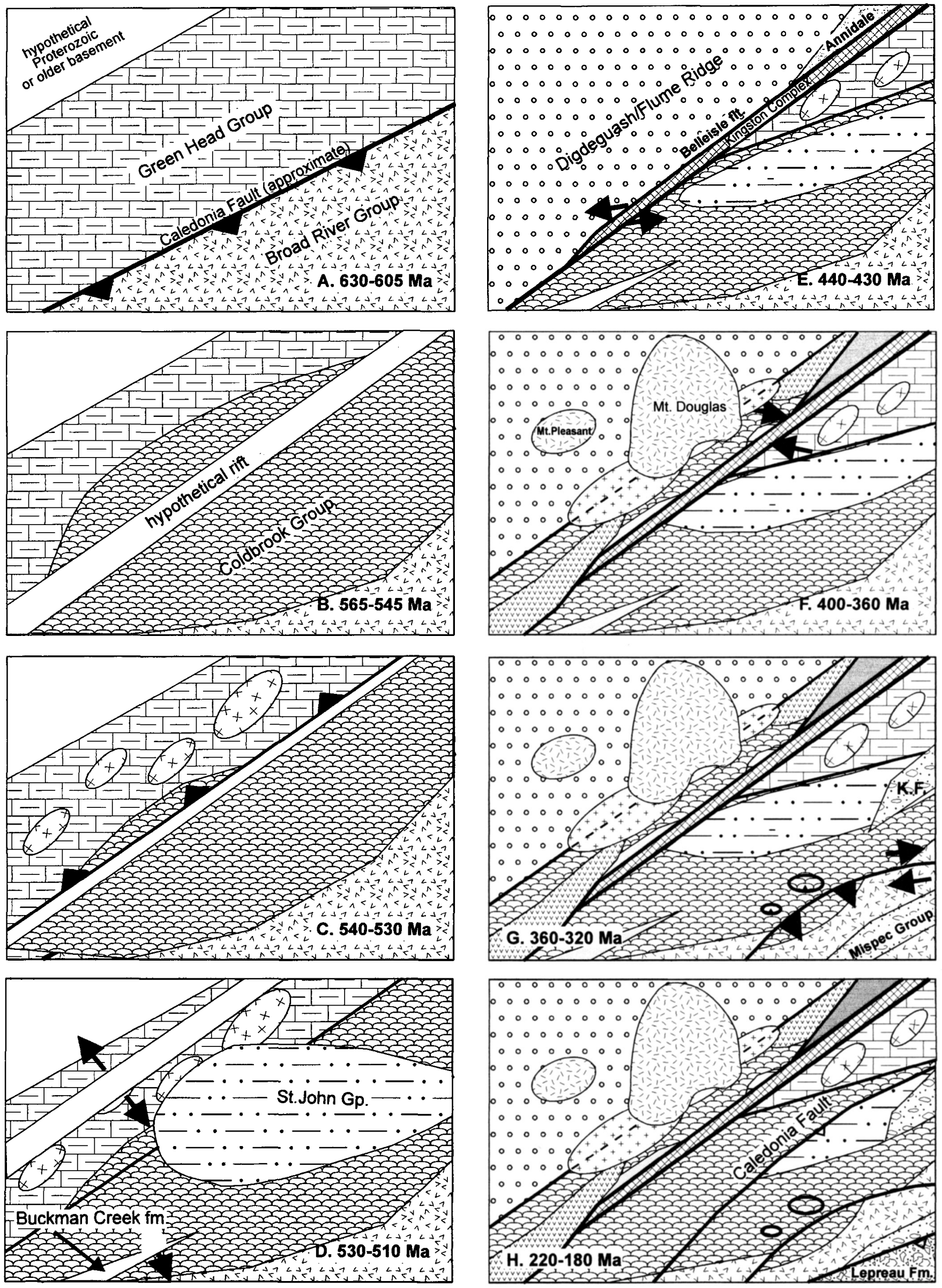
Brookville and Mascarene-Caledonia blocks. In this model the Saint John Group was deposited on a thermally subsiding passive margin subsequent to this collision. Cambrian igneous activity on this margin may indicate further rifting, which left the Brookville block as a tiny remnant attached to the MascareneCaledonia block, and facing an oceanic basin in which the Digdeguash, Sand Brook and Flume Ridge formations were deposited.

(d) By 440 Ma this ocean had largely closed by northwestdirected subduction. Post-closure sinistral transtension along the former continent-ocean margin opened pull-apart basins forming sites for the deposition of sedimentary and mafic volcanic rocks (lower Mascarene Group), and the emplacement of sheeted dikes of the Kingston Complex.

(e) At about 430-400 Ma, motion reversed to dextral transpressive. Dextral motion along the northern boundary of the Kingston Complex moved the Mascarene block north of the Brookville block and Kingston Complex from an original position to the southwest (present orientation). The transpressive component of this hypothetical motion may have moved the Mascarene block southward over the relatively fixed mantle magmatic source of the Kingston Complex, causing magmatism to migrate northwest and become more continental in character. (f) Insulation of the residual mantle upwelling by over-riding crustal material produced a final, climactic igneous outburst 40 million years later $(360 \mathrm{Ma})$, essentially inverting a large part of the crust (Mount Douglas pluton and Mount Pleasant caldera).

(g) Continued dextral transpression produced pull-apart basins, accommodating Carboniferous clastic sequences at releasing bends and thrust allochthons at compressional bends. We assume that the Brookville and Kingston blocks were uplifted and tilted during this process, leaving residual fault slivers of younger rocks as evidence of alternate compressive and extensional motions.

(h) Opening of the Atlantic Ocean produced normal faulting along the Bay of Fundy, opening half-graben basins in which the Triassic Lepreau Formation was deposited, and Saint John Group and Coldbrook Group strata in the Caledonia block preserved by east-side-down motion on the Caledonia Fault.

\section{ACKNOWLEDGEMENTS}

The staff of the Geochronology Laboratory of the Geological Survey of Canada is thanked for their assistance in generating the U-Pb data.

BARR, S.M., BEVIER, M.L., WHITE, C.E., and DOIG, R. 1994. Magmatic history of the Avalon terrane in southem New Brunswick based on
U-Pb (zircon) geochronology. Journal of Geology, 102, pp. 399 409

BARR, S.M., and WHITE, C.E. 1999. Field relations, petrology and structure of Neoproterozoic rocks in the Caledonian Highlands, southem New Brunswick. Geological Survey of Canada, Bulletin $530,101 \mathrm{p}$.

BARR, S.M., and WHTTE, C.E. 1996. Contrasts in late Precambrian-early Paleozoic tectonothermal history between Avalon composite terrane sensu stricto and other possible peri-Gondwanan terranes in southem New Brunswick and Cape Breton Island, Canada. Geological Society of America, Special Paper, 304, pp. 95-108

BARR, S.M., WHITE, C.E., and MCLEOD, M.J. 1997. Geology of the Kingston Peninsula, southem New Brunswick: a preliminary report. In Current Research 1966. Edited by B.M.W. Carroll. New Brunswick Department of Natural Resources and Energy, Minerals and Energy Division Mineral Resources Report 97-4, pp. 1-20

BEVIER, M.L., and BARR, S.M. 1990. U-Pb age constraints on the stratigraphy and tectonic history of the Avalon Terrane, New Brunswick, Canada. Journal of Geology, 98, pp. 53-63

BEVIER, M.L., WhITE, C.E., and BARR, S.M. 1990. Late Precambrian U$\mathrm{Pb}$ ages for the Brookville Gneiss, southern New Brunswick. Journal of Geology, 98, pp. 955-965

CURRIE, K.L. 1987. Late Precambrian igneous activity and its tectonic implications, Musquash-Loch Alva region, southern New Brunswick. Geological Survey of Canada, Paper 87-1A, pp. 663671

CURRIE, K.L. 1997. Geology of the Saint John-Saint George area, New Brunswick (revised). Geological Survey of Canada, Open File 3418

CURRIE, K.L., and HUNT, P.A. 1991. Latest Precambrian igneous activity near Saint John, New Brunswick. Geological Survey of Canada Paper 90-2, pp. 11-17

CURRIE, K.L., and NANCE, R.D. 1983. A reconsideration of the Carboniferous rocks of Saint John, New Brunswick. Geological Survey of Canada Paper 83-1C, pp. 29-36

DALLMEYER, R.D., and NANCE, R.D. 1992. Tectonic implication of ${ }^{40} \mathrm{Ar}{ }^{39} \mathrm{Ar}$ mineral ages for Late Precambrian-Cambrian plutons, Avalon composite terrane, southern New Brunswick, Canada. Canadian Journal of Earth Sciences, 29, pp. 2445-2462

DaVIS, W.J., McNicoll, V.J., BEllerive, D.R., SANTOWSKI, K., and SCOTT, D.J. 1997. Modified chemical procedures for the extraction and purification of uranium from titanite, allanite and rutile in the Geochronology Laboratory, Geological Survey of Canada. Radiogenic Age and Isotopic Studies, Report 10, Geological Survey of Canada, Current Research 1997-F, pp. 33-35

DoIG, R., NANCE, R.D., MuRPHY, J.B., and CASSEDAY, R.P. 1990. Evidence for Silurian sinistral accretion of Avalon terrane in Canada. Geological Society of London Journal, 147, pp. 927-930

EBY, G.N., and CURRIE, K.L. 1993. Petrology and geochemistry of the Kingston Complex - a bimodal sheeted dike suite in southem New Brunswick. Atlantic Geology, 29, pp. 121-135

EBY, G.N., and CURRIE, K.L. 1996. Geochemistry of the granitoid plutons of the Brookville terrane, Saint John, New Brunswick and implications for the development of the Avalon Zone. Atlantic

Fig. 6. Cartoon of a possible tectonic history for the Saint John region. (a) 630-605 Ma; Subduction beneath a Gondwanan margin, collision with a continent with the Green Head Group as a passive margin sequence, formation of the Broad River Group and correlative plutons. (b) 565-545 Ma; mantle upwelling (due to crustal delamination?) producing bimodal and $\mathrm{A}_{2}$-type magmatism (Coldbrook Group and correlative plutons), metamorphism and rifting. (c) 540-530 Ma; Large-scale magmatism (Hanson Stream and correlative plutons) due to subduction beneath the Brookville block, reuniting it with the Mascarene-Caledonia block. (d) 530-510 Ma; Deposition of a Saint John Group on a thermally subsiding margin. Persistent rifting and igneous activity leading to continental break-up. (e) 440-430 Ma; Post-closure sinistral transtension along the former continent-ocean margin, forming pull-apart basins, emplacement of Kingston Complex, deposition of Mascarene Group. (f) 430-360 Ma; Dextral transpressive motion. Emplacement of the Mascarene block and over-thrusting of the Kingston block by the Mascarene block causing magmatism to migrate northwest leading to climactic emplacement of Mount Douglas pluton and Mount Pleasant caldera. (g) 360-320 Ma; Continued dextral transpression, pull-apart basins, filled by clastic sequences, thrust allochthons at compressional bends, fault slivers of Saint John Group formed. (h) 220-180 Ma; Opening of the Atlantic Ocean, normal faulting along the Bay of Fundy, deposition of Lepreau Formation, downfaulting of Caledonia block. 
Geology, 32, pp. 247-268

FYFFE, L.R., and MLLER, R.F. 1992. A note on reported plant fossils from the Flume Ridge area of southwestern New Brunswick. Atlantic Geology, 28, pp. 215-220

FYFFE, L.R., and FRICKER, A. 1987. Tectonostratigraphic terrane analysis of New Brunswick. Maritime Sediments and Atlantic Geology, 23, pp. 113-123

HELMSTAEDT, H. 1968. Structure analysis of the Beaver Harbour area, Charlotte County, New Brunswick. unpublished Ph.D. thesis, University of New Brunswick, Fredericton, $196 \mathrm{p}$.

JoHNSON, S.C and MCLEOD, S.J. 1996. The New River Belt: a unique segment along the western margin of the Avalon Composite Terrane, southern New Brunswick, Canada. Geological Society of America, Special Paper 304, pp. 149-164

JOHNSON, S.C., MCLEOD, M.J., and KROGH, T.E. 1993. Geology and Geochronology of the Fowle Lake area: evidence for Late Cambrian volcanism in southern New Brunswick (abstract). Atlantic Geology, 29, p. 83

KEPPIE, J.D., and MURPHY, J.B. 1988. Anatomy of a telescoped pullapart basin: an example from the Cambro-Ordovician rocks in the Antigonish Highlands of Nova Scotia. Maritime Sediments and Atlantic Geology, 24, pp. 123-138.

KROGH, T.E. 1982. Improved accuracy of U-Pb ages by the creation of more concordant systems using an air abrasion technique. Geochimica et Cosmchimica Acta, 46, pp. 637-649.

LANDING, E. 1996. Avalon: insular continent by latest Precambrian. Geological Society of America, Special Paper 304, pp. 29-64

LEgER, A., and WILLIAMS, P.F. 1986. Transcurrent faulting history of southern New Brunswick. Geological Survey of Canada, Paper 861B, pp. 111-120

MCCUTCHEON, S.R. 1990. The Late Devonian Mount Pleasant caldera complex; stratigraphy, mineralogy, geochemistry and geological setting of a Sn-W deposit in southwestern New Brunswick. unpublished Ph.D. thesis, Dalhousie University, Halifax, 609 p.

MCLEOD, M.J. 1990. Geology, geochemistry and related mineral deposits of the Saint George batholith, Charlotte, Queens and Kings Counties, New Brunswick.. New Brunswick Department of Natural Resources and Energy Mineral Resources Report 5, 169 p.

MCLEOD, M.J., JOHNSON, S.C., and RUTTENBERG, A.A. 1994. Geological map of southeastem New Brunswick, New Brunswick Department of Natural Resources and Energy Map NR-6

MCLEOD, M.J., RUITENBERG, A.A., and KROGH, T.E. 1992. Geology and $\mathrm{U}-\mathrm{Pb}$ geochronology of the Annidale Group, southern New Brunswick; lower Ordovician volcanic and sedimentary rocks formed near the southem margin of Iapetus Ocean. Atlantic Geology, 28, pp. 181-192

NANCE, R.D., and DALLMEYER, R.D. $1993 .{ }^{40} \mathrm{Ar} /{ }^{39} \mathrm{Ar}$ amphibole ages from the Kingston Complex, New Brunswick: evidence for SiluroDevonian tectonothermal activity and implications for the accretion of the Avalon composite terrane. Journal of Geology, 101, pp. 375-388

NANCE, R.D., and THOMPSON, M.D. 1996. Avalonian and related periGondwanan terranes of the Circum-North Atlantic: An Introduction. Geological Society of America, Special Paper 304, pp. 1-9.
Park, A.F., Williams, P.F., RalSER, S., and Leger, A. 1994. Geometry and kinematics of a major crustal shear zone segment in the Appalachians of southern New Brunswick. Canadian Journal of Earth Sciences, 31, pp. pp. 1523-1535

PARRISH, R.R., RODDICK, J.C., LOVERIDGE, W.D., and SULLIVAN, R.W. 1987. Uranium-lead analytical techniques at the geochronology laboratory, Geological Survey of Canada. Radiogenic age and isotopic studies: Report 1, Geological Survey of Canada, Paper 87. 2, pp. 3-7.

PAYETTE, C., and MARTIN, R.F. 1987. The Welsford igneous complex, southern New Brunswick; rift-related Acadian magmatism. Geological Survey of Canada, Paper 87-1 A, pp. 239-248

RAST, N., and DICKSON, W.L. 1982. The Pocologan mylonite zone. Geological Association of Canada, Special Paper 24, pp. 249-262.

RoDDICK, J.C. 1987. Generalized numerical error analysis with applications to geochronology and thermodynamics. Geochimica et Cosmchimica Acta, 51, pp. 2129-2135.

SHIVES, R. 1986. Airborne gamma-ray spectrometer surveys, Saint John (west half), New Brunswick. Geological Survey of Canada Map $35721 \mathrm{G}$ (8 sheets)

van Staal, C.R., Sullivan, R.W., and Whalen, J.B. 1996. Provenance and tectonic history of the Gander Zone in the Caledonian/Appalachian orogen: Implications for the origin and assembly of Avalon. Geological Society of America, Special Paper 304, pp. 347-367

WARDLE, R.W. 1978. The stratigraphy and tectonics of the Greenhead Group: its relation to Hadrynian and Paleozoic rocks. unpublished Ph.D. thesis, University of New Brunswick, Fredericton, 187 p.

WATTERS, S.E. 1993. Geology of the Cape Spencer-Black River area, New Brunswick. New Brunswick Department of Natural Resources and Energy, Mineral Resources Plate 93-15A

Whalen, J.B., CuRRIE, K.L., BARR, S.M., JENNER, G.E., and HEgENER, E. 1994. Geochemical and isotopic characteristics of granitoids of the Avalon Zone, southern New Brunswick: Possible evidence for repeated delamination events. Journal of Geology, 102, pp. 79-93

WHITE, C.E. 1995. Geology, geochronology and tectonic evolution of the Brookville terrane, southern New Brunswick. unpublished Ph.D. thesis, Dalhousie University, Halifax, 513 p.

WHITE, C.E., and BARR, S.M. 1996. Geology of the Brookville terrane, southem New Brunswick, Canada. In Avalonian and Related PeriGondwanan Terranes of the Circum-North Atlantic. Edited by R.D. Nance and M.D. Thompson. Geological Society of America, Special Paper 304, pp. 133-147

WILliAMS, H. 1995. Geology of the Appalachian-Caledonian orogen in Canada and Greenland. Geological Survey of Canada, Geology of Canada, Volume 6, $921 \mathrm{p}$.

ZAIN EldEen, U., YAN, N., Hunter, I.M., NANCE, R.D., DoIG, R., and DALLMEYER, R.D. 1991. Late Carboniferous sedimentation and tectonics in the Chance Harbour-Dipper Harbour area, southern New Brunswick, Canada. Geological Society of America Abstracts with Program, 23, p. 153

Editorial Responsibility: S.M. Barr 